\title{
Proline-, Glutamic Acid- and Leucine-Rich Protein 1
}

National Cancer Institute

\section{Source}

National Cancer Institute. Proline-, Glutamic Acid-and Leucine-Rich Protein 1. NCI

Thesaurus. Code C92153.

Proline-, glutamic acid- and leucine-rich protein 1 (1130 aa, 120 kDa) is encoded by the human PELP1 gene. This protein is involved in steroid receptor-dependent transcription. 